\title{
E-Language Pedagogy the Go-to? Attitude of the College language tutor towards Technology Integration
}

\author{
Daniel Arkoh Fenyi ${ }^{1}$, John Andoh ${ }^{2}$, Enoch Mensah Awukuvi ${ }^{3}$ \\ ${ }^{1}$ Department of Applied Linguistics, University of Education, Winneba (PhD c) \\ ${ }^{2}$ Department of Languages, Enchi College of Education \\ ${ }^{3}$ Department of Languages, Enchi College of Education \\ Correspondence-Daniel Arkoh Fenyi:Tel-0242937017: Email: fenyigh@gmail.com
}

\begin{abstract}
This paper investigates how Ghana, a developing country with her corresponding less technologically oriented education system, in the wake of the coronavirus disease, adapts, adopts and resorts to technology integration through online teaching and learning at the tertiary level, specifically, Colleges of Education. The study is a qualitative research work, which adopts the descriptive case study approach. The major data collection instruments were participant observation and semi-structured interviews. 29 language tutors spread across 4 language backgrounds- English, French, Fante and Twi, were interviewed. The data revealed that though technology is important and inevitable in the $21^{\text {st }}$ century educational system, it cannot replace the traditional face-to-face classroom setting completely. It was clear also that the teacher's attitude towards technology was very critical in the integration process. The study recommends that teachers be given technical support, training and adequate access to IT resources and infrastructure if integration can be done effectively to achieve the desired results.
\end{abstract}

KEYWORDS: technology integration, education system, classroom, IT resources, infrastructure

DOI: $10.7176 / \mathrm{JEP} / 11-30-14$

Publication date:October $31^{\text {st }} 2020$

\section{$1.1 \quad$ INTRODUCTION}

"With the help of technology, teachers will be leaders in the transformation of education around the world"Craig R .Barrett

On the 15th of March, 2020, the President of the Republic of Ghana, Nana Addo Dankwa Akufo-Addo, in a speech which would become the second in a series of speeches to be delivered on the management of the Coronavirus disease in Ghana, announced a temporary closure of all schools, from the kindergarten level to the tertiary level. In the speech, the President intimated clearly that

all Universities, Senior High Schools, and basic schools, i.e. public and private schools, will be closed Monday, $16^{\text {th }}$ March, 2020, till further notice. The Ministry of Education, in collaboration with the Ministry of Communication, has been tasked to roll out distance learning programmes. However, BECE and WASSCE candidates will be allowed to attend school to prepare for their examinations, but with prescribed social distancing protocols.

It must be indicated that the BECE and WASSCE candidates who were asked to stay in school in preparation towards their final examinations, were later, in a statement released by the Ghana Education Service on $20^{\text {th }}$ March, 2020, asked to go home after some concerns were raised by teacher unions and other stakeholders coupled with the suspension of the West African Secondary School Certificate Examination (WASSCE) by West African Examination Council (WAEC). The statement opined clearly that the "Management of GES after consultations with the relevant bodies hereby directs that all final year students in the Senior High Schools should be allowed to go home immediately until further notice". These announcements came on the back of the dreadful Coronavirus disease which had engulfed most parts of the world.

Social and physical distancing have been argued by many health professionals and bodies including the World Health Organisation (WHO) to be one of the safety measures in the fight against the disease. However, the school, which is seen to be one of the fertile grounds for socialisation (Tekinarslan, 2008), poses some appreciable risk in suspending these safety protocols, therefore, its temporary closure.

Following the suspension of the traditional classroom face-to-face system of teaching and learning, most teaching and learning practices were conveyed online and through other electronic media. For example, the Ghana Education Service (GES) brought out teaching and learning via radio and television with an introduction of a new television channel called Ghana Learning Television (GL TV) supported by the already existing state-owned radio station, i.e., the Ghana Broadcasting Corporation (GBC) radio, with outlets across the country. Also, most tertiary institutions introduced various relatively student-friendly virtual classrooms such as Moodle, Google classroom, Sakai and other social media platforms like webinar (zoom), telegram, whatsapp, etc into the teaching and learning process. 
These arrangements contravene Rhema and Miliszewska's (2014) position that in many countries, especially the developing ones, like Ghana, it is almost impossible to take the learning and teaching process away from the traditional classroom. In such contexts, therefore, the application of technological tools in the teaching and learning process is considered to be an interference of the traditional practices held in high esteem. According to van Dyk, van der Merwe, Thomas and Brown (2008), the socio-cultural make-up of an environment or country determines how welcoming or otherwise the people are in adopting electronic teaching methods and such setting with strong socio-cultural setting is Ghana. To them (ibid), students in such settings acquire a most part of their knowledge out of their interaction with the real learning classroom.

The prevailing global health situation, however, has generally reduced the reserved attitude students and teachers had towards technology-based facilities or tools for teaching and learning, not only as a result of the voluntary realisation of the obvious significance of these tools but also as a result of the undeniable relevance of the tools without which teaching and learning would literally be halted until the disease is over.

The traditional methods and approaches to the learning and teaching of language have severed some challenges by the innovation and new approaches that internet-based technology brings to language teaching. Undeniably, the vast opportunities and resources that the internet and computers provide have given rise to new strategies, approaches and tools in the teaching and learning of language (Siragusa \& Dixon, 2008).

It is argued that for the implementation of technology to be successful in any educational process or programme, it strongly depends on the attitudes and support of the teachers (Gilakjani \& Leong, 2012). Umay and Asker (2001) also emphasise that teachers are likely to oppose any efforts at introducing and implementing technology in the teaching and learning process if they perceive or believe that the technology is not able to fulfil their students' or their own needs. Computers and internet-based technology, generally, are widespread increasingly and are having a serious influence on different facets of work and social lives, even extending to several leisurely activities. As more personal and occupational responsibilities in recent times revolve around human-computer interface and interaction, knowledge and skills in computer have been linked to both personal and occupational competence and success. Therefore, as society becomes more technology based, it's imperative that the classroom and learning experiences of teachers and students be fairly incorporated into technology. The teacher, in most cases, is very instrumental in the effective and efficient implementation of the use of internetbased technology in the educational process and system (Gilakjani \& Leong, 2012). Given that the teacher has incredible capability to transmit values and beliefs to the learners, it is important to appreciate and understand the stereotypes and biases which the teacher could have with regards to computer use in the teaching and learning process, especially, of language.

In relation to the factors which have been considered as determining the successful implementation of computers in the learning environment, the attitude of the teacher, be it negative or positive, is highly rated. It is in this light that Huang and Liaw (2005) argue that irrespective of how powerful and sophisticated the state or condition of technology is, if the teacher has a positive attitude towards it, its use and implementation can be successfully done. Teo (2006), in emphasising the importance of the teacher's attitude towards computer use, reasons that even the way and manner in which the learners view and approach the use and importance of computers are affected by the teacher's attitude. Also, Mishra, Tan and Zhao (2001) accentuates the significance of the teacher's attitude towards the use of computer by suggesting that the teacher's attitudes are related directly to the use of computer in the language classroom. Teo (ibid) further argues that the teachers' attitude and their readiness to embrace and use technology largely determine the learner's success in language learning with computer and internet-based technology. Trucano, Hawkins and Iglesias's (2012) position, that gaining some appreciation and understanding into the teachers' attitudes vis-à-vis their use of internet-based technology in the language teaching and learning process provides very important insights and depths into technology integration, is a fundamental hypothesis on which this current study is based. It is anticipated that the insights this paper puts forward informs better planning and decision making on how technology can seamlessly be fully integrated into the (language) curriculum, at least, at the College of Education level.

\subsection{RESEARCH OBJECTIVES}

The study aims to

1. identify how the integration of technology impacted on the role of the language teacher.

2. describe the advantages, if any, that technology integration has on language teaching (over the traditional teaching practices).

3. determine the factors which ensure effective integration of technology in language teaching.

\subsection{RESEARCH QUESTIONS}

1. How has the integration of technology impacted the role of the language teacher?

2. What are the advantages of technology integration, if any, on language teaching (over the traditional teaching practices)?

3. What factors would ensure effective integration of technology in language teaching, from the teacher's point of view? 


\subsection{SIGNIFICANCE OF THE STUDY}

All major and relevant stakeholders of education such as the government, teachers, students, curriculum planners and developers, school Information Technology management experts and policy makers shall be adequately informed about the attitudes of tutors towards the use and integration of ICT in the language teaching process. This will shape future decisions and directives on the convenient and appropriate use and incorporation of ICT into the teaching and learning of language. Bork (2003) opines that the opinions, beliefs and perspectives that teachers hold about Technology, to a very large extent, influence their attitudes towards the use of it, therefore, this study's interest in investigating the perception of teachers towards Technology's impact on the teaching process helps to unveil and justify the effects and (in)efficient use of same on language teaching. The study documents the results and findings on College of Education language tutors' attitudes towards ICT integration in the teaching and learning process, and therefore becomes a reference for further and future studies, as well.

\subsection{WHAT IS TECHNOLOGY INTEGRATION?}

Before one could take a firm decision on how and the best means to integrate technology into the teaching and learning process, the first thing to do is to be able to define what technology integration precisely is/means and what it is not (Jolene, 1999). Technology has, in this 21 st century, undeniably become one of, if not the most, powerful forces and/or tools in driving political, social, economic and educational transformations (Jhurree, 2005). It is argued that countries, especially developing ones such as Ghana and many other African countries, in their strife and bid to competing in the global space and economy, cannot afford to be unreceptive and passive towards the use of ICT (Guskey, 1989; Hadley \& Sheingold, 1993). The health of any country's economy, be it rich or poor, developing or developed, substantially depends upon the quality, level and depth of the education its workforce is provided (Allan \& Will, 2001).

Most parts of the world, if not every part, is undergoing education reforms in different shapes and forms and among the significant tenets of these reforms is the introduction and integration of Technology in the system of education (Jhurree, ibid). The efficient and effective integration of technology into the education system largely depends on how policy makers and implementers, that is, the tutors, appreciate and understand the dynamics that such integration entails. Keengwe, Onchwari and Wachira (2008) opine that when ICT is effectively and efficiently integrated and used, additional educational opportunities could even be provided.

ICT, in this study, adopts, at least to start with, Anderson's (2010, pg. 4) definition that, it is an "allencompassing term that includes the full gamut of electronic tools by means of which we gather, record and store information, and by means of which we exchange and distribute information to others". ICT includes, internetbased computers, laptops, tablets, Web 2.0 technologies, electronic pads, and predominantly among tertiary students, smartphones. The study admits that though Anderson's definition of ICT provides some good foundational platform for analysis, it is relatively narrow in its scope.

In fact, Davies (2013) accentuates that efforts to critique and describe the present use and integration of technology in the classroom must appreciate and recognise the fact that different people hold different understanding and perspectives of what technology actually means and what technology integration entails. Technology, to many people, just like Anderson above, means and is synonymous with electronic devices and computer hardware/equipment and software while technology integration means to have and use these devices and softwares in the teaching and learning environment or classroom (Woolfe, 2010). These definitions, however, are inarguably narrow. Limiting the concept of technology integration to the mere access and use of computer hardware and software and other internet-based electronic devices has led many scholars into thinking of technology integration into the school system and curriculum as a simplistic answer to a rather complex endeavour (Cuban, 2006; Bahrampour, 2006; Warschauer \& Ames, 2010).

Let us be clear on what technology integration is not. Technology integration is not just about placing computers or electronic devices in the classroom without adequately training and preparing the teacher (Jolene, 1999). The integration cannot happen when the teacher who will use the devices to teach has not been given the necessary skills and the know-how to operate and manipulate these devices. Again, integration is not just about replacing 30 minutes of reading with 30 minutes of 'pressing' the computer. However, it is about being able to manipulate computers and devices to effectively teach and conduct 30 minutes of reading (ibid). Also, integration is not just the provision of application software such as electronic databases, spreadsheets, encyclopaedias, etc with no purpose. It is also not programmes created by the teacher to cover his technical expertise and/or special interests which do not necessarily fit into the core content of the curriculum.

Technology integration, rather, pays particular focus on the creative and innovative best practices of using developing and new digital technologies to enhance and aid the teaching and learning of new concepts (Woolfe, 2010). Technology integration is the efficient and effective use of computer and electronic devices in the core content areas of the curriculum in order for the learners to be able to understand, use and apply computer knowledge and skills to do several things (Jolene, 1999). Integration has to do with the incorporation of technology into the teaching and learning process in a manner that ensures that students' learning abilities are enhanced. It is important to understand that technology integration is more generally about using the curriculum to drive the usage 
of technology and not about technology rather driving the curriculum (ibid). Integration is the use of computer software applications that enable students to use computers creatively, purposefully and flexibly. And finally, integration of technology into the curriculum is the organising of the goals of technology and curriculum into a harmonious, coordinated whole.

For this study, technology integration is defined as the effective and efficient implementation or use of educational technology in order to have the estimated learning outcomes accomplished. Educational technology is considered to be any piece of equipment, tool, or device- mechanical or electronic- which can be employed in the teaching and learning process to aid the learners achieve learning objectives and goals (New, Sprague \& Davies, 2008).

Currently, ICT has become so relevant and powerful that, whether to use or not in the education system is rarely the question. Valanides and Angeli (2008) assert that, the focus of the question is rather on what should constitute effective integration. And therefore, the measure of the usefulness and success of technology in the education system lies in its effective integration. It is also established that it is necessary to integrate technology as a core component of the basic curriculum and not offer it as some external elective programmes (Keengwe \& Anyanwu, 2007). Pasco and Adcock (2007) also emphasise that the huge resources, in terms of time and money invested in ICT can only be considered to be well spent if instructors are able to effectively integrate technology into the classroom such that authentic and active learning opportunities are incorporated into the curriculum.

The concept of technology integration into education and its impacts have not gone without scholarly contentions. In one breadth, some scholars are not fully convinced and do not subscribe to the much touted pedagogical benefits of ICT in education (Cuban, 1986; Postman, 1995; Oppenheimer, 1997; Vestich, 1997; McRobbie and Thomas, 1998; Peat and Franklin, 2003). In another, some scholars claim that integrating technology into the curriculum has the potency of bringing some remarkable transformation in the educational landscape endlessly and in such a way that the performance of students will be dramatically enhanced (Edison as cited in Saettler, 1990; Negroponte, 1995; Papert, 1996). There is a third breadth to the technology integration argument. This group of scholars and ideology have a balanced appreciation and approach to the integration of technology in education. Their conviction is that if the integration is properly implemented, the teaching and learning process will be enhanced but when otherwise done, education suffers greatly (Dwyer, Ringstaff, and Sandholtz, 1990; Lee and Dziuban, 2002; Apkan, 2002; Kian-Sam, Abang \& Ming-Koon, 2003; Thompson, 2003; Bork, 2003). Whitworth and Berson (2003) also emphasise that, when the ICT integration is properly done, there is the potential that the learners' problem solving skills, decision-making abilities, processing of data and digital literacy, and communication skills will be developed.

\subsection{LITERATURE REVIEW}

The attitudes of teachers towards technology integration and the underlining factors that determine, affect and change such attitudes have received some substantial scholarly attention and enquiries (Sugar, Crawley \& Fine, 2004; Jimoyiannis \& Komis, 2007; Tondeur, Hermans, Van Braak \& Valcke, 2008; Lau \& Sim, 2008). Only that, many of these earlier studies have looked at integration from an interdisciplinary dimension where teachers with backgrounds in several/different disciplines were the focus of investigation.

Cox, Abbott, Blakeley, Beauchamp \& Rhodes (1999) report that teachers who placed premium on technology integration often changed their style of teaching just to be able to integrate technology approaches better. Sepehr and Harris (1995) also argue that the availability of computer software and the willingness of the teacher to integrate it into the teaching and learning process can bear some positive effects on the attitude of the teachers and even their students. Moreover, teachers who are found to have a firm commitment to their own professional and personal development and enough commitment towards teaching have been identified as being able to readily integrate technology (Hadley \& Sheingold, 1993; Becker, Ravitz \& Wong, 1999).

Norum, Grabinger and Duffield (1999) conducted a study on the growth, knowledge, experiences, beliefs, perceptions, and thoughts of teachers who were studying and making attempts to integrate the use of technology in the classroom. The significant theme they observed as running through the research was the strong assertion of the teachers that, in order to have technology effectively integrated into the classroom, they needed to have a change in their person and teaching skills and assume new roles. Majority of the teachers who participated in the study considered themselves as the first focal point in which change efforts had to start. The role and importance of the teacher and his attitude towards the success or otherwise of technology integration cannot be overemphasised. The concept rises and falls with the teacher. Therefore, there is the need to consider, engage and coordinate with teachers and integrate their concerns in the planning and designing process of technology integration in the education system (Ross, Hogaboam-Gray, \& Hannay, 1999; Albion, 1999). While positive attitudes of the teachers towards integration of technology enhances teaching and learning, their negative attitudes restrain it (Gilakjani \& Leong, 2012).

Woodrow, in early 1992, observed that the introduction and infusion of technology into the educational curriculum came along with radical transformation in educational practices. However, in order to have the traditional teaching and instructional practices changed successfully, instructors are to possess positive attitudes 
concerning the educational matters or issues that are involved. If teachers do not accept the innovative changes in the educational curriculum which arises out of the integration of technology, they tend to resist the change and therefore the integration's tendency to succeed becomes very slim (Gilakjani \& Leong, 2012). This is particularly the case with any technologically-based educational innovation especially because such change and innovation come with mandatory acquisition of new technology pedagogies and skills (Saye, 1998).

Allan and Will (2011) did a study and measured the attitudes of teachers towards the use of technology in the teaching and learning process. The attitudes of the teachers, they found out, to a very large extent, depend on the extent to which educational managers and investors are ready to effectively invest in computer technology in order to assist the successful integration of technology in the teaching and learning process. They confirm that the attitude of teachers towards the adoption of technology are a major disabling/enabling factor (Bullock, 2004).

Similarly, Kersaint, Horton, Stohl, and Garofalo (2003) realised that teachers whose attitudes were positive towards the integration of technology always felt happy and more comfortable incorporating it into their lessons. They assert that for any successful innovation and transformation to take place in educational practice, the development of positive user perception and behaviour towards new technology is required. The attitude of the teachers towards technology integration, when it is positive, Watson (1988) argues, does not only ensure successful teaching and learning but also helps to avoid the teachers' potential resistance to the use of computer. Watson (ibid) warns that in the planning process towards the integration of technology, the teacher must be fully involved and not treated as some empty vessel into which decisions must be poured. When that happens, there is the tendency that the teacher will resist and passively involve himself in the implementation stage where he is most needed. It is obvious from the earlier studies which have been discussed above that, even though technology integration is very important, especially in the 21 st century education system, the role of the language teacher in ensuring its success or otherwise cannot be overemphasised.

\subsection{METHOD AND DESIGN}

This work is a qualitative research, which adopts the descriptive case study design. Zainal (2007) argues that the descriptive case study design gives some description and depth into natural phenomenon and gives insight into complex life issues within the framework of the investigated data. Lambert and Lambert (2012) hold the view that the overall ambition of any qualitative descriptive study is to give a report on the lived experiences of the participants or individuals. The researchers, in their quest to appreciate, describe and understand the perceptions, attitudes and experiences of language tutors transitioning from the traditional face-to-face classroom teaching and learning environment to a technologically integrated one, consider the qualitative descriptive case study design as the ideal approach which will aid in arriving at some competitively comprehensive outcome (Yin, 2013; Harrison, 2017).

Through purposive sampling, a total of 29 College of Education language tutors participated in the study and were interviewed. These tutors were pragmatically selected from the Ashanti-Brong Ahafo (AshBa) zonal division of the Colleges of Education in Ghana. The AshBa zone was considered for the study due to the 'easy' access, readiness and availability of the participants. The tutors were selected from various language backgrounds; 10 English tutors, 8 French tutors, 4 Fante tutors and 7 Twi tutors. It must be noted that, the disparities in the quantity of discipline-based teachers used for the study (i.e. 10, 8, 4 and 7 English, French, Fante and Twi tutors respectively) did not affect the outcome of the study in any significant way since the study was neither comparative nor quantitative and did not intend to make numeral or statistical arguments (Yunus, Nordin, Salehi, Sun \& Embi, 2013).

Participant observation and semi-structured interview were the major data collection instruments used for this study. The researchers themselves are College of Education language tutors and therefore had first-hand information and practical experiences on how the integration of technology panned out. They also belong to common 'College of Education language tutors' virtual platforms with the respondents where general ideas and experiences were exchanged among language tutors across various colleges to ensure even development and progress in the teaching and learning of language via internet-based technology. The in-depth semi-structured interviews sought to also provide, aside the observation, some comprehensive perspectives and views on what the respondents perceive (Yunus et al, 2013). The interview questions were structured such that they directly responded to the research questions. In the process of developing the interview questions, the researchers, in order for the validity of the content to be ensured, reviewed relevant and empirical literature and closely scrutinised the interview protocols which were designed for similar exercises. The interview questions were piloted on 4 language tutors across the 4 languages used for the study- English, French, Fante and Twi, in order to ensure the reliability of the questions. The piloting revealed that there were no serious challenges with the questions and that they were clearly expressed and easy to understand. All the interviews were conducted in August, 2020 when the semester was supposed to have ended. English Language was used as the language of interaction, for direct and easy transcription. Each interview lasted about 35 minutes and they were audio-recorded and relevant portions were transcribed. 
In analysing the data obtained from the interview, quite a number of steps were followed. Firstly, immediately after each interview session, the audio-record of the interactions were transcribed. The researchers also jotted down some notes during the interview, which they made references to during the transcription process in order to avoid the possibility of losing any important information which could have some significant bearing on the outcome of the research. And finally, the respondents were contacted, after the transcription, to confirm or deny the accurateness of the transcriptions and determine if they reflected their original positions and inputs, as the researchers had interpreted. They also had the opportunity to change or make amends to their earlier inputs. The data were then collated, coded and examined critically.

Ethically, participation in the study was uncompromisingly voluntary. No respondent was coerced, through whatsoever means, to take part in the study. Each participant had the opportunity to withdraw from the study at any point he/she felt so. Also, all participants were informed to understand and append the modalities and conditions of participation before appending their consent. No identifiable data on individual participants were taken. This was to ensure a high level of anonymity and protection of the privacy of the respondents (Ngo \& Eichelberger, 2019).

\subsection{RESULTS}

\subsubsection{How has the integration of technology affected the role of the language teacher?}

The focus of this enquiry was to understand how the teachers saw their (new) role during the semester where they had to, due to the coronavirus disease, completely depend on and use internet-based technology in teaching language. From the responses, one thing was consensual, in that, all the tutors agreed that their roles had changed. What had not been unanimous in their responses is the degree of change that the integration had brought. While a group thinks that their roles had significantly been affected and changed, another group thinks that their roles had mildly been affected. This aligns with Davies' (2013) assertion that different people see technology integration in different ways. The first group of tutors who consider their roles to be significantly affected spoke about a range of issues.

Firstly, to them, body language and gestures, which play very important roles in the whole teaching and learning process were hampered in the virtual classroom. The virtual platforms that were considered to be most student-friendly were Telegram and WhatsApp. And therefore, most of the online class sessions were conducted with texts exchanges and not live video. Even with the few times where videos were involved, they were prerecorded, and not live. This, to them, made concepts that could best be explained with role plays and dramatization suffer greatly since all such concepts, in the technology integration era, needed to be explained orally. A tutor recounted

You know, for teaching and learning to be successful, it's not only about the notes and explanations of same given the students, but also the body language, intonation, movements of the lips, hands, legs and the entire body language contribute to the comprehension process. These were lacking in the online system. The students did not see us. At best, they heard our voice.

Another tutor, in agreement with the body language argument, posits that, My role as tutor has really been affected. Concepts that in the face-to-face class session would need just a few minutes to explain with the aid of body language, dramatization and role play, now needed very lengthy explanations because there was no way the students could be helped to understand them pictorially.

Also, the tutors recounted that assessment system was significantly affected. In the traditional classroom, tutors would administer tests on paper and mark them. However, with technology, the teachers no longer needed to mark tests. The computer was programmed to mark and give instant feedback to multiple-choice questions. This is a major deviation from the traditional classroom where ordinarily, students would get their feedback weeks later. This also meant that remedial exercises were to be instantly delivered. A tutor couldn't agree more

In terms of assessment, my role has been affected. Hitherto, I would administer a test, after which the scripts would be collected and marked. The period of marking would afford me the opportunity to adequately prepare on the remedial exercises and strategies to employ going forward. However, with technology integration, marking of scripts has been instant giving me no opportunity to adequately study the difficulty pattern of the students to inform my next remedial strategies.

One other tutor who affirms that her role has been affected relative to assessment also indicated that since the computer could not be programmed to mark subjective tests, like essay questions, they were forced to give only multiple choice questions to the students. This, to her, affected the argument-building skills she wanted to build in the students this academic year. She insinuates:

This particular semester, my aim was to build in my students the ability to make and push cogent arguments in essay writing and speaking. But you know, we are not able to programme the computers to 
assess subjective essay type questions. This has grossly affected my style of teaching. I was not able to effectively achieve that. I needed to set objective multiple choice questions for the students anytime I had to assess them.

Another change or effect on the traditional teaching system was on the giving of notes to students. One important observation made from the responses of the tutors was that, the degree of change or effect on their traditional roles, to a very large extent, depended on the language they taught. Those who taught English Language did not face much difficulty as those who taught local languages. For those who taught English, they argued that all the characters they needed to speak and write texts were naturally programmed in the computer so they did not need any extra efforts converting characters from one language to another. This, to them, did not completely change their roles in terms of note giving. One indicated

In terms of giving notes to students, nothing seriously changed apart from the fact that there was no 'chalkboard' to write some notes on as characterised in the traditional classroom setting. Normally, I type-write my notes and print them out for the students. With this integration thing, I still type-wrote the notes, only that, this time round, I gave the notes to the students in the form of softcopies. This is the little way, I would say, my work in terms of note giving was affected.

Another English tutor added that:

Because computers are already programmed in English, it is easy to type in the same language. Therefore, even though I would admit that my role in the giving of notes was affected, the effect was mild. It wasn't entirely different from what I have been doing in the traditional classroom setting. Previously, I would type write my notes, print it out and when I went to class, would write them on the board for the students to copy. However, with this integration system, though I still type write the notes, I am unable to write them on any board so I sent them directly to the students in soft copy.

However, the teachers of Fante and Twi complained bitterly on how tedious it had become for them to type write their notes. Their difficulty arose because the computer is not programmed in the local language and therefore, before they were able to write, they had to look for some softwares which could aid them capture the local language characters. A thing they found very difficult especially on occasions they could not even obtain such softwares. This, to them, is a complete departure from their note giving roles in the traditional classroom setting where all their notes were written on the 'chalkboard' hence there was no need to secure any software. A Fante tutor elaborated

Indeed, note giving under the technology system has greatly changed. It has become very tedious. We are not able to get some of the local language characters in the computer and therefore, we are compelled to resort to softwares that have them. Even after managing to put something down, we are compelled to convert the notes into PDF formats for security. Tutors whose phones are not compatible with PDF files are therefore not able to open the files and share with the learners.

A Twi language tutor also added that

Throughout the entire semester, I have not been able to give my students any notes. I only record my voice and send to them to play and listen. That is the only form of notes I have been able to give my students which is totally different from how I would have dealt with the situation in the traditional classroom setting.

From the foregoing, one thing is obvious and constant- there is a change in the roles of the language teacher. These changes are seen in three major areas of the teaching and learning process, that is, non-verbal communication, assessment and note giving. It is also evident from the responses that how teachers see the impact of technology on their work depends on the language they taught. To the English tutor, nothing significant had changed but with the local language tutors, they have been significantly affected.

\subsubsection{What are the advantages of technology integration, if any, on language teaching (over the traditional teaching practices)?}

While some scholars assert that the use of technology is good in education, others think that it is unduly complicated in use and makes no significant contribution to education (Cuban, 1986; Postman, 1995; Papert, 1996; Oppenheimer, 1997; Vestich, 1997; McRobbie and Thomas, 1998; Apkan, 2002; Whitworth and Berson, 2003; Peat and Franklin, 2003). The focus of this second research question was therefore to understand, in practical terms, how beneficial or otherwise, technology has been to the language teacher. And, from the responses of the participants, there was mixed reactions towards the impact of technology on teaching, in line with the earlier studies. 
The first and most common among the advantages is the fact that, with technology, teaching and learning could happen anytime and anywhere (Oppenheimer, 1997; Yang and Kwok, 2017). Most of the tutors admitted that, but for technology, the coronavirus-laden semester would have been called off which would have inadvertently disturbed the nation's academic calendar. Technology therefore has been able to take education outside the four walls of the classroom and, that, to them, was extremely positive. A tutor indicated that,

Technology has been the saviour for this semester. The semester would have been called off if not for technology. Our educational life would have come to a standstill and that was going to have dire consequences on the nation's academic calendar.

Another tutor who couldn't hold back on the benefits of technology said that,

I could sit comfortably in my room and still teach. That is the most amazing part of this technology thing. I remember I once held a lecture while responding to nature's call. Teaching could just happen anywhere and anytime.

Another advantage that came up was the instant test scores and feedback that technology gave the learners on administered tests. The tutors described as beneficial the ability of computers to be programmed such that students instantly had their test scores. Tutors were not burdened with volumes of papers to mark. Technology, therefore, was time and energy saving. A tutor recounted

One thing I like about technology integration is the instant test scores it delivers. I didn't have to go through the rigorous exercise of marking volumes of scripts and recording the marks.

Another tutor who also benefitted from the instant test scoring ability of technology explained

I am the only tutor who takes the entire school. My students number about 700 and they all answered 40 objective test questions. If not for technology, I would have been marking 2,800 test items. When would I have finished if not for technology. I think every tutor should take integration seriously.

However, not all tutors think highly of technology integration. Others believe that it has no serious positive impact on education. They argued, for instance, that it was not easy teaching certain concepts online. Especially, concepts that involved role plays and dramatization. A tutor indicated

I didn't enjoy the integration. I couldn't teach most of my lessons. I needed my students physically in the classroom so that they could dramatise some of the concepts. For example, with a concept like "Puberty" in Fante, my students would have demonstrated and role played how newly menstruated lady is ushered into adulthood.

4.1.3 What factors would ensure effective integration of technology in language teaching, from the teacher's point of view?

With respect to the factors that could ensure that technology integration is effectively and efficiently carried out in language teaching and learning process, the respondents listed such factors as technical support and training, support from school management, access and availability of ICT resources and infrastructure, personal characteristics, competence in ICT, self-efficacy in computer and the positive attitudes of teachers and students towards integration of ICT.

On technical support and training, many of the tutors indicated that the major tool for the online teaching was their personal smart phones, tablets and laptops, but when these tools break down, the school is not able to help fix them. Many recounted several instances where they had to suspend class sessions because their phones or laptops broke down and the school was not ready to offer technical assistance. This confirms Becta (2004) and Yusuf and Afolabi's (2010) report that, with technology integration, if regular maintenance is not done and ICT technical team is not on standby to step in in times of need, both the students and the teachers will become frustrated which could translate into their unwillingness to use technology in their learning and teaching respectively. One tutor said emphatically that

My laptop broke down and when I consulted the Principal, he told me to find money myself and repair it because the school has no arrangement for such cases. For about two weeks, my lectures were suspended because 'I was looking for money'. I don't even know what the ICT tutors do in this school. I think the school should charge them to offer assistance in such cases.

Another tutor who also faced similar technical challenge recounted a worrying instance;

My major tool for this online teaching is my tablet. A month ago, it was infected with virus and as a result, I lost all my documents and reference materials which I use to teach. I was looking for an IT person to format and restore my lost documents but got none in the school. Technical support is a serious problem to us here. I am so much frustrated and don't even know what to do. 
Another factor for effective integration of technology was personal characteristics. With that, issues such as gender, age, previous experience with computers and educational background were given by the respondents, and observed by the researchers, as factors that ensure effective technology integration. The personal characteristics factor in technology integration is in line with Schiller's (2003) position that these characteristics must be considered very well in any serious educational programme that wish to successfully integrate technology. On age, a tutor in his late fifties said;

For me, I was born before computer so it is really difficult adopting this technology system. I don't find it easy at all. Sometimes, it is my children who help me to upload some of the documents but when they are not around, I go through hell. I think the young tutors will be more comfortable with the computer thing than those of us who are nearing pension.

Another tutor also reported on how she thinks her gender stands in the way of smoothly integrating technology in her teaching;

You know that with us women, we are not gadgets oriented. We are not fond of manipulating gadgets like the way men are comfortable doing. The way guys are active and would briskly go about fixing, using and setting up gadgets, I think it is not the same with us women. I know a lot of my female colleagues who find this online thing too technical and manly, hence feel very frustrated.

Again, to have ICT initiated and implemented successfully into the teaching and learning process, the attitudes of tutors cannot be taken for granted. Attitude, belief and perception of tutors have great influence on how successful or otherwise integration turns out. Fear, lack of confidence, anxiety, and lack of competence are behaviours which are considered to influence ICT use (Norum et al, 1999). Keengwe and Onchwari (2008) also add that when teachers perceive ICT to be helpful in meeting their teaching needs, then they are likely to develop positive attitudes towards it and integrate it well. Therefore, a good understanding of the attitudes, beliefs and perceptions which influence and determine the teachers' integration and adoption of technology into their teaching is not only relevant, but also, necessary.

A French tutor who doesn't perceive integration to be an effective tool in teaching talks about how his teaching needs are inadequately met;

I see this ICT nonsense to be unnecessarily complicated. It doesn't solve any problem but rather adds more. It is difficult to find most of the French language characters on the keys. And even when I record my voice too, it doesn't come clear because I learnt there is a problem with my speaker. I have not been able to successfully treat a single topic with my students. I think it should be abolished so we go back to the traditional classroom.

Another tutor also shares his belief about integration

I don't see how this internet-based teaching and learning has solved any teaching problem. There's nothing serious that I have been able to teach. Any time I have a lecture session, one problem or the other crops up. I am just waiting for schools to re-open so I teach everything again. I can't depend on the eteaching system.

From the foregoing, it is clear that several key factors contribute to the effective implementation of technology integration. Without the appropriate measures instituted, it will be difficult to ensure that teaching and learning of language is made technologically friendly for the tutors. Each of the factors pointed out above is paramount to the tutors and must be afforded the needed attention.

\subsection{DISCUSSION}

The study found out that the tutor's role in the traditional face-to-face classroom underwent some changes in the internet-based technologically integrated one, as argued by Siragua and Dixon (2008). The changes in the roles could be identified in three aspects of the teaching and learning process- non-verbal communication in the classroom setting, assessment and giving of lecture notes. With non-verbal communication or gestures, there was substantial difference in what pertains in the traditional classroom setting and the online classroom. With the former, teachers could move their mouths, hands, legs, heads, etc freely in ways that could add meanings to what they taught. However, on the computer, such movements were restricted, especially because most of the media were audio and text biased.

Also, in terms of assessment, the integration ensured instant test scores and feedback anytime multiple choice tests were administered to the students. This largely departed from the traditional system where tutors would spend weeks to mark scripts. Nonetheless, they admitted that the integration took away their ability to vary the assessment tools. In that, subjective items were avoided entirely because of programming difficulties in the ICT integration, meanwhile, at the end of the semester, some subjective test items were used for the summative assessment. Also, with the giving of lecture notes, changes in the traditional setting depended on the language 
backgrounds of the tutors. For example, to English tutors, their roles did not change completely. However, with the L1 and French language tutors, their roles and difficulty level in gathering notes were affected because some of the language characters were not programmed in the computer.

The study also identified that, the tutors considered, at varying degrees, that technology had some advantages. These advantages, broadly, manifested in two major areas- academic setting and assessment. In terms of setting, technology integration ensured that teaching and learning of language is not constrained to any particular place or time setting. This advantage could be situated in Yang and Kwok (2017). Physical setting did not place any limitations on when and where lectures could be held. In fact, an instance was recalled of a respondent who indicated that he held a successful lecture while responding to nature's call. Also, in terms of assessment, tutors benefitted significantly from technology. They were relieved of the cumbersome task of having to mark lots of papers and test items over a long period of time and record same as well. With technology, computers were programmed such that students could instantly be given their scores of tests and tutors would receive automated record of the students' marks in their emails. The respondents indicated that this saved them a lot of time and energy. However, for its inability to ensure that certain concepts that involved role play and dramatization be effectively taught, some tutors considered technology not to be any better alternative to the traditional classroom setting.

Lastly, with respect to factors that ensure effective technology integration, two categories of factors came up- internal (school based) factors and tutor based factors. With the internal factors, participants indicated factors as: technical support and training by school management, financial support from school management, access and availability of ICT resources and infrastructure, among others. With the tutors' based factors, respondents listed factors as: background experience in ICT, competence in ICT, age and gender, self-efficacy in ICT, confidence, tutors' perception/attitude towards integration, among others.

\subsection{LIMITATIONS AND RECOMMENDATIONS}

The study and its outcome could be subjected to two general limitations- social desirability of respondents and ecological generalisability of the results. The open-ended and self-report nature of the data collection instrument- semi-structured interview, opened participants up for social desirability biases in their responses such that they could over or under report their experiences with technology integration (Becta, 2004). This makes it difficult to claim $100 \%$ objectivity of the results. Also, the study limited itself to language tutors and Colleges of Education. Caution must therefore be taken when generalising the results to cover the experiences of tutors from other disciplines and from other tertiary establishments like universities, polytechnics, professional institutions, among others. The study recommends that future research works could look at a comparative analysis of the experiences of language tutors- say, English tutors vrs Fante tutors. A clear observation of the participants shows that, attitudes of the language tutors were language specific, for example, the English tutors' challenges/attitude significantly varied from the local language tutor, hence a comparative study would be very enlightening. A future study, hence, might want to delve into that space. Again, future works may want to cover other tertiary institutions.

\subsection{CONCLUSION}

The purpose of this study was to establish and investigate the Ghanaian College of Education Language tutor's attitude towards technology integration in the teaching and learning process. The study has attempted a demonstration of how descriptive qualitative analysis gives some appreciable insights into the integration of technology in the teaching of language, from the perspective of the language instructors. Two major conclusions can be drawn from the study. Firstly, the integration of technology is good but it cannot replace completely the traditional face-to-face classroom system. In a densely socio-cultural context like Ghana where people's personal and physical affiliations and backgrounds influence their understanding of taught concepts, it is highly impractical to turn to a $100 \%$ internet-based technology system of teaching and learning where human interface is drastically effaced. That will make teaching and learning a very difficult process. Secondly, technology integration comes with corresponding effects and changes in the traditional role of the teacher. This implies that tutors must be given adequate orientation, preparation, training and technical support if they can effectually and efficiently use and manipulate technology to yield the desired results.

\section{REFERENCES}

Allan, Y., \& Will, M. (2001). Teachers' computer attitudes: Factors influencing the instructional use of computers. Paper presented at the International Conference on Computers in Education, Seoul, Korea.

Albion, P. R. (1999). Self-efficacy beliefs as an indicator of teachers' preparedness for teaching with technology. Paper presented at the 1999 annual Society for Information Technology in Teacher Education conference, San Antonio, TX, December.

Anderson, J. (2010). ICT transforming education: A regional guide. Bangkok: UNESCO.

Apkan, J. P. (2002). Which comes first: Computer simulation of dissection or a traditional laboratory practical method of dissection? Electronic Journal of Science Education, 
$6(4)$

Bahrampour, T. (2006). For some, laptops don't computer: Virginia school pushes wireless learning. Washinton Post, p.1.

Becker, H., Ravitz, J., \& Wong, Y. (1999). Teacher and teacher-directed student use of computers and software. Teaching, Learning, and Computing: 1998 National Survey. Report \#3.

Becta. (2004). A review of the research literature on barriers to the uptake of ICT by teachers. Retrieved August 12, 2020, from http://partners.becta.org.uk/page_documents/research/barriers.pdf.

Bork, A. (2003). Interactive learning: Twenty years later. Contemporary Issues in Technology and Teacher Education, 2(4).

Bullock, D. (2004). Moving from theory to practice: An examination of the factors that preservice teachers encounter as they attempt to gain experience teaching with technology during field placement experiences. Journal of Technology and Teacher Education, 12(2), 211-224.

Cox, M., Webb, M., Abbott, C., Blakeley, B., Beauchamp, T., \& Rhodes, V. (1999). ICT and pedagogy: A review of the literature. British Educational Communications and Technology Agency, Department for Education and Skills.

Cuban, L (1986). Teachers and Machines: The Classroom Use of Technology Since 1920. New York: Teachers College Press.

Cuban, L. (2006). Commentary: The laptop revolution has no clothes. Education Week, p. 29. Retrieved from http://www.edweek.org/ew/articles/2006/10/18/08cuban.h26.html

Davies, R. S., West, R. \& Young, W. (2013). Technology Integration in Schools. Retrieved at $3.26 \mathrm{pm}$ on $25^{\text {th }}$ August 2020 from https://www.researchgate.net/publication/260363660

Davies, R., Sprague, C., \& New, C. (2008) Integrating technology into a science classroom: An evaluation of inquiry-based technology integration. In D.W. Sunal, E.L. Wright, \& C. Sundberg (Eds.), The impact of technology and the laboratory on K-16 science learning series: Research in science education (pp. 207-237). Charlotte, NC: Information Age Publishing, Inc.

Dwyer, D. C., Ringstaff, C., and Sandholtz, J. H. (1990). Apple Classrooms of Tomorrow: Teacher Beliefs and Practices Part I: Patterns of Change. Apple Computer.. http://images.apple.com/education/k12/leadership/acot/pdf/rpt08.pdf [Accessed 23 August 2020].

Gilakjani, A. P. \& Leong, L.M (2012). EFL Teachers’ Attitudes toward Using Computer Technology in English Language Teaching. Theory and Practice in Language Studies, Vol. 2, No. 3, pp. 630-636.

Guskey, T. (1989). Attitude and perceptual change in teachers. International Journal of Educational Research, 13, 439-453.

Hadley, M., \& Sheingold, K. (1993). Commonalities and distinctive patterns in teachers ${ }^{\text {ee }}$ integration of computers. American Journal of Education, 101, 261-315.

Harrison, H., Birks, M., Franklin, R. and Mills, J. (2007), "Case study research: foundations and methodological orientations", Forum: Qualitative Social Research, No. 1, retrieved at $4.35 \mathrm{pm}$ on 22 August 2020 from http:// search.ebscohost.com/login.aspx ?direct $=$ true $\&$ AuthType $=$ shib $\& \mathrm{db}=$ edsdoj\&AN $=$ eds doj.2 959900b435b4c988812267188f7b1 f8\&site=eds-live\&scope=site

Huang, H. M., \& Liaw, S. S. (2005). Exploring user's attitudes and intentions toward the web as a survey tool. Computers in Human Behavior, 21(5), 729-743.

Jhurree, V. (2005). Technology integration in education in developing countries: Guidelines to policy makers1. International Education Journal. 6(4), 467-483.

Jimoyiannis A. \& Komis V. (2007). Examining teachers' beliefs about ICT in education: implications of a teacher preparation programme, Teacher Development 11(2) 149-173.

Jolene, D. (1999) Teachers of the 21st century know the what, why, and how of technology integration. T H E Journal, Vol. 26 Issue 6, p73, 2p

Keengwe, J., \& Anyanwu, L. O. (2007). Computer technology-infused learning enhancement. Journal of Science Education and Technology, 16, 387-393.

Keengwe, J. (2007). Faculty integration of technology into instruction and students' perceptions of computer technology to improve student learning. Journal of Information Technology Education, 6, 169-180. 
Keengwe, J., Onchwari, G., \& Wachira, P. (2008). The use of computer tools to support meaningful learning. Association for the Advancement of Computing in Education Journal, 16, 77-92.

Kersaint, G., Horton, B., Stohl, H., \& Garofalo, J. (2003). Technology beliefs and practices of mathematics education faculty. Journal of Technology and Teacher Education, 11(4), 549-577.

Kian-Sam Hong, Abang Ahmad Ridzuan and Ming-Koon Kuek. (April, 2003). Students' attitudes toward the use of the Internet for learning: A study at a university in Malaysia. Educational Technology and Society, 6(2), 45-49.

Lambert, V.A. and Lambert, C.E. (2012), "Editorial: qualitative descriptive research: an acceptable design", Pacific Rim International Journal of Nursing Research, 16 (4), pp. 255-256.

Lau, B. T. \& Sim, C. H. (2008). Exploring the extent of ICT adoption among Secondary school teachers In Malaysia. International Journal of Computing and ICT Research, 2 (2). 1936.

Lee, L. and Dziuban, C. (2002). Using quality assurance strategies for online programs. Educational Technology Review: International Forum on Educational Technology Issues and Applications, 2(2).

McRobbie, C. J. and Thomas, G. P. (1998). The use of microcomputer-based learning in senior chemistry: Does technological innovation always result in improved student learning? Paper presented at the Australian Association for Research in Education, 1998. [Online]. http://www.aare.edu.au/ 98pap/mcr98120.htm [Accessed 4 August, 2020].

Mishra, P., Tan, H. S. \& Zhao, Y. (2001). Teaching and learning: Whose computer is it? Journal of Adolescent \& Adult Literacy, 44(4), 348-354.

Negroponte, N. (1995). Being Digital. New York: Vintage Books.

Ngo, H. \& Eichelberger, A. (2019) College students' attitudes toward ICT use for English learning. International Journal of Education and Development using Information and Communication Technology (IJEDICT), 2019, Vol. 15, Issue 1, pp. 231-244

Norum, K., Grabinger, R. S., \& Duffield, J. A. (1999). Healing the universe is an inside job: teachers' views on integrating technology. Journal of Technology and Teacher Education, 7(3), 187-203.

Oppenheimer, T. (July, 1997). The computer delusion. The Atlantic Online, 280(1). http://www.theatlantic.com/issues/97jul/computer.htm [Accessed August 18 2020].

Papert, S. (1996). The Connected Family: Bridging the Digital Generation Gap. Atlanta: Longstreet Press.

Pasco, B., \& Adcock, P. G. (2007). New rules, new roles: Technology standards and teacher education. Educational Considerations, 34(2), 29-31.

Peat, M., and Franklin, S. (2003). Has student learning been improved by the use of online and offline formative assessment opportunities? Australian Journal of Educational Technology, 19(1), 87-99.

Postman, N (1995). The End of Education: Redefining the Value of School. New York: Knopf.

Rhema, A., \& Miliszewska, I. (2014). Analysis of student attitudes towards e-learning: The case of engineering students in Libya. Issues in Informing Science and Information Technology, 11, 169-190.

Ross, J. A., Hogaboam-Gray, A., \& Hannay, L. (1999). Predictors of teachers' confidence in their ability to implement computer-based instruction. Journal of Educational Computing Research, 21(1), 75-97.

Saettler, L. P. (1990). The Evolution of American Educational Technology. Englewood CO: Libraries Unlimited.

Saye, J. W. (1998). Technology in the classroom: The role of disposition in teacher gate keeping. Journal of Curriculum and Supervision, 13(3), 210-234.

Sepehr, H., \& Harris, D. (1995). Teachers ${ }^{\text {ee }}$ use of software for pupils with specific learning difficulties. Journal of Computer Assisted Learning, 11, 64-71.

Siragusa, L., \& Dixon, K. (2008). Planned behaviour: Student attitudes towards the use of ICT interactions in higher education. In Hello! Where are you in the landscape of educational technology? Proceedings ascilite Melbourne 2008. Retrieved August 17, 2020, from http://www.swaraunib.com/indra/Sistem\%20informasi/TPB/siragusa.pdf

Sugar, W., Crawley \& Fine, B. (2004). Examining teachers' decisions to adopt new technology. Educational Technology and Society, 7(4), 201-213 
Tekinarslan, E. (2008). Computer anxiety: A cross-cultural comparative study of Dutch and Turkish university students. Computers in Human Behavior, 24(2008), 1572-1584.

Teo, T. (2006). Attitudes toward computers: A study of post-secondary students in Singapore. Interactive Learning Environments, 14(1), 17-24.

Thompson, S. S.(2003). Using technology to promote critical thinking through the natural sciences. TecKnowLogia, 5(1), 38-9. Knowledge Enterprise. [Online]. http://www.techknowlogia.org/ [Accessed 16 August, 2020].

Tondeur, J., Hermans, R., van Braak, J., \& Valcke, M. (2008). Exploring the link between teachers educational beliefs profiles and different types of computer use in the classroom: The impact of teacher beliefs. Computers in Human Behavior, 24, 25412553.

Trucano, M., Hawkins, R., \& Iglesias, C. J. (2012). Ten trends in technology use in education in developing countries that you may not have heard about. A World Bank Blog on ICT use in Education. Retrieved August 17, 2020 from http://blogs.worldbank.org/edutech/some-more-trends

Umay, A. \& Askar, P.(2001). Pre-service elementary mathematics teachers ${ }^{\text {ee }}$ computer selfefficacy, attitudes towards computers, and their perceptions of computer enriched learning environments. In Proceedings of Society for Information Technology and Teacher Education International Conference 2001 pp. 2262-2263. AACE, Chesapeake, VA.

Valanides, N., \& Angeli, C. (2008). Professional development for computer-enhanced learning: a case study with science teachers. Research in Science \& Technological Education, 26, 3-12.

van Dyk, L., Brown,C., Thomas, H., \& van der Merwe, A.(2008). The impact of South Africa's ICT infrastructure on higher education. In D. Remenyi (Ed.), 3rd International Conference on E-Learning: ICEL 2008, Cape Town, South Africa. Academic Publishing Limited. Retrieved August 17, http://www.cet.uct.ac.za/files/file/ResearchOutput/2008 ICEL Landscape.pdf

Vestich, E. L. (1997). Review of the book- Silicon snake oil: Second thoughts on the information highway. Journal of Educational Technology, 9(1).

Warschauer, M., \& Ames, M. (2010). Can one laptop per child save the world's poor? Journal of International Affairs, 64(1), 33-51.

Watson, D. M. (1998). Blame the technocentric artifact! What research tells us about problems inhibiting teacher use of IT. In G. Marshall, \& M. Ruohonen (Eds.), Capacity building for IT in education in developing countries, 185-192. London: Chapman \& Hall.

Whitworth S., and Berson, M. (2003). Computer technology in the social studies: An examination of the effectiveness literature (1996-2001). Contemporary Issues in Technology and Teacher Education, 2(4).

Woodrow, J. E. (1992). The influence of programming training on the computer literacy and attitudes of pre-service teachers. Journal of Research on Computing in Education, 25(2), 200-218.

Woolfe, B.P. (2010). A roadmap for education technology. Retrieved at 2.12pm on August 24, 2020 from http://www.cra.org/ccc/docs/groe/GROE\%20Roadmap $\% 20$ for $\% 20$ Education $\% 2$ 0Technology\%20Final\%20Report.pdf

Yang, S. \& Kwok, D. (2017). A study of students' attitudes towards using ICT in a social constructivist environment. Australasian Journal of Educational Technology, 33(5).

Yin, R.K. (2013), Case Study Research: Design and Methods, Applied Social Research Methods, 5th ed., Sage, Los Angeles, CA.

Yunus, M.M., Nordin, N., Salehi, H., Sun, C.H. \& Embi, M.A. (2013). Pros and Cons of Using ICT in Teaching ESL Reading and Writing. International Education Studies; 6 (7)

Yusuf, M. O., \& Afolabi, A. O. (2010). Effects of computer assisted instruction (CAI) on secondary school students' performance in biology. The Turkish Online Journal of Educational Technology,9(1), 62-69

Zainal, Z. (2007), "Case study as a research method”, Jurnal Kemausiaan, Vol. 9, pp. 1-6. 